\title{
Selected mental health problems in institutionally reared children
}

\author{
Wybrane problemy z zakresu zdrowia psychicznego wśród nastolatków \\ w wychowaniu instytucjonalnym
}

\author{
Department of Adolescent Psychiatry, Chair of Psychiatry, Medical University of Lodz, Łódź, Poland \\ Correspondence: Rafał Szmajda, Department of Adolescent Psychiatry, Chair of Psychiatry, Medical University of Lodz, Czechosłowacka 8/10, 92-216 kódź, Poland, \\ tel.: +48795009696, e-mail: rafalszmajda87@gmail.com
}

\author{
Klinika Psychiatrii Młodzieżowej, I Katedra Psychiatrii, Uniwersytet Medyczny w Łodzi; w strukturze Oddziału Psychiatrii Młodzieżowej Centralnego Szpitala Klinicznego Uniwersytetu Medycznego w Łodzi, \\ Łódź, Polska \\ Adres do korespondencji: Rafał Szmajda, Klinika Psychiatrii Młodzieżowej Uniwersytetu Medycznego w Łodzi, Centralny Szpital Kliniczny Uniwersytetu Medycznego w Łodzi, \\ ul. Czechosłowacka 8/10 (bud. B-1: Psychiatria), 91-738 Łódź, tel.: +48 795009 696, e-mail: rafalszmajda87@gmail.com
}

Abstract Aim of the study: The aim of the study was to assess the mental condition of institutionally reared children as compared to individuals brought up by their parents. Method: Based on data collected by the Department of Adolescent Psychiatry, University of Lodz, in the years 2006-2012, four groups of patients were formed according to their place of residence/type of care they were provided with. The sample group included 1,308 patients hospitalised at the Department of Adolescent Psychiatry. The group that participated in the study included 794 girls and 514 boys aged 13-18 years. Results: In the sample group girls were more often brought up in foster families. The most commonly diagnosed problems among hospitalised children brought up in institutions are behavioural and emotional disorders (diagnostic categories from F90 to F98) and almost half of the subjects showed this type of disorders. The percentage rate of self-injuries and suicide attempts is higher in groups of children raised in foster families and education and care facilities. The average age of developing mental disorders is lower among children raised in foster families and the institutional rearing system. In the group of children raised in foster families and the institutional rearing system a higher number of hospitalisation cases were observed. Conclusions: 1) Institutionally reared children and adolescents suffer from self-injuries or even make suicide attempts more often than their peers brought up in two-parent families. 2) The average age of mental disorder onset among children raised in institutions and foster families is lower; they are also hospitalised more often than their peers brought up by parents. 3) Institutional rearing is a factor that gives a poorer prognosis for mental disorders among children and adolescents, just as living with a non-parent caregiver (a guardian).

Keywords: mental health, orphanages, institutionalisation, adolescents, suicide

Streszczenie Celem pracy była ocena wybranych problemów z zakresu zdrowia psychicznego u nastolatków wychowywanych w placówkach opiekuńczo-wychowawczych i rodzinach zastępczych, w porównaniu z młodzieżą wychowaną przez rodziców. Badanie opiera się na danych populacji pacjentów hospitalizowanych w Klinice Psychiatrii Młodzieżowej Uniwersytetu Medycznego w Łodzi. Metoda: Z bazy danych gromadzonych w latach 2006-2012 w Klinice Psychiatrii Młodzieżowej wyodrębniono cztery grupy pacjentów - na podstawie kryterium miejsca zamieszkania lub rodzaju sprawowanej nad nimi opieki. Badaniami retrospektywnymi objęto populację 1308 pacjentów, w tym 794 dziewcząt i 514 chłopców, w wieku 13-18 lat. Wyniki: W badanej grupie pieczą zastępczą częściej objęte były dziewczęta. Najczęstsze rozpoznanie, z którym hospitalizowane są dzieci wychowywane w instytucji, stanowią zaburzenia zachowania i emocji (grupa rozpoznań F90-F98). Wykazywało je prawie co drugie badane dziecko. Odsetek samouszkodzeń i prób samobójczych jest istotnie wyższy w grupach młodych osób wychowywanych w pieczy zastępczej i w placówkach opiekuńczo-wychowawczych niż w porównywanej grupie wychowywanej przez rodziców. Średnia wieku zapadania na zaburzenia psychiczne okazała się znacznie niższa w przypadku pieczy zastępczej i wychowania instytucjonalnego. W tej grupie dzieci zaobserwowano też istotnie większą liczbę hospitalizacji. Wnioski: 1) Dzieci i młodzież wychowywane w placówkach częściej niż ich rówieśnicy z rodzin pełnych, a nawet zastępczych, dokonują samouszkodzeń i prób samobójczych. 2) Dzieci w wychowaniu instytucjonalnym oraz w pieczy zastępczej mają niższą średnią wieku, w którym zapadają na zaburzenia psychiczne, niż ich rówieśnicy wychowywani w rodzinie; są też hospitalizowane częściej od rówieśników wychowywanych z rodzicami. 3) Wychowanie instytucjonalne jest czynnikiem pogarszającym rokowanie w zaburzeniach psychicznych dzieci i młodzieży, podobnie jak zamieszkiwanie z opiekunem niebędącym rodzicem. 


\section{INTRODUCTION}

I nstitutional rearing is an independent risk factor for developing mental illnesses both among children and adults. A large number of studies prove that children raised in various institutional settings, e.g. orphanages, are exposed to a higher risk of developing mental disorders and illnesses. Research on this subject was conducted in the United States of America, Great Britain, Germany and Romania. There are also individual reports from Poland. American studies show that $63.3 \%$ of institutionally-reared children and adolescents suffer from mental problems, with $22.8 \%$ being diagnosed with three or more conditions (Jackson et al., 2010). Among the most commonly diagnosed mental illnesses there were: oppositional-defiant disorders (29.3\%), behavioural disorders (the so-called severe ones; $20.7 \%)$, recurrent depressive disorders (19.0\%), depressive episodes (19\%), anxiety disorders with panic attacks (18.9\%) and attention deficit hyperactivity disorder (ADHD; 15.1\%) (Jackson et al., 2010).

In the 1970s, a study was conducted in the United Kingdom on mental disorders in children from educational institutions. Children aged 4.5 years old who were admitted to the facility before 4 months of age and remained there for at least 2 years were examined. The frequency of mental disorders was not determined in these studies as compared to the group raised in families. However, it was noticed that children in institutional care present a different nature of the disorder compared to their peers living with the family (Tizard and Rees, 1975).

Another study conducted in the United Kingdom in a school in one of London's districts, which included children aged 10-11 years who presented with psychiatric disorders, indicated that in the group that benefited from state care the prevalence of disorders was $17 \%$, compared to only $2 \%$ in the group of children who had never been under the care of the state (Wolkind and Rutter, 1973).

McCann et al. (1996) carried out a study on a group of adolescents aged 13-17 who were sent to state care (both to 24 -hour outlets and foster care). The results were compared to the control group. The prevalence of mental disorders in the study group was $57 \%$. Young people in 24 -hour centres showed mental disorders in $96 \%$ of cases, compared to young people in foster care where mental disorders occurred in $57 \%$ of respondents.

In a study carried out by Graf in Germany, the prevalence of psychiatric disorders in children from educational institutions was found to be $80 \%$ (Graf et al., 2002). Another German study carried out by Schmid showed the prevalence of mental disorders to be $59.9 \%$ (Schmid, 2008; Schmid et al., 2008).

Another example is the study conducted in preschool children brought up in orphanages and family-type orphanages in Bucharest. Throughout 54 months of the study period duration, $53 \%$ of children were diagnosed with a mental problem, whereas the percentage rate of mental disorders in

\section{WSTĘP}

$\mathrm{W}$ ychowanie instytucjonalne jest niezależnym czynnikiem ryzyka rozwoju chorób psychicznych - zarówno w wieku dziecięcym, jak i u dorosłych. Istnieje duża liczba badań pokazujących, że dzieci wychowywane w instytucjach, takich jak domy dziecka, odznaczają się większym ryzykiem rozwoju chorób i zaburzeń psychicznych. Badania na ten temat prowadzone były w Stanach Zjednoczonych, Wielkiej Brytanii, Niemczech i Rumunii. Istnieją również pojedyncze doniesienia $\mathrm{z}$ Polski.

Według badań amerykańskich 63,3\% dzieci i młodzieży $\mathrm{w}$ wychowaniu instytucjonalnym przejawia problemy ze zdrowiem psychicznym, przy czym $22,8 \%$ ma trzy i więcej diagnoz (Jackson et al., 2010). Spośród diagnoz psychiatrycznych najczęściej występowały: opozycyjno-buntownicze zaburzenia zachowania (29,3\%), zaburzenia zachowania (tzw. poważne; 20,7\%), zaburzenia depresyjne nawracające $(19,0 \%)$, epizody depresji (19\%), zaburzenie lękowe z napadami paniki (18,9\%) i zaburzenia hiperkinetyczne z deficytem uwagi (attention deficit hyperactivity disorder, ADHD; 15,1\%) (Jackson et al., 2010).

W Wielkiej Brytanii już w latach 70. ubiegłego wieku przeprowadzono badanie nad zaburzeniami psychicznymi u dzieci w instytucjach wychowawczych. Badano dzieci w wieku 4,5 roku, które zostały przyjęte do placówki przed 4. miesiącem życia i przebywały w niej przynajmniej 2 lata. Nie określono w tych badaniach częstości zaburzeń psychicznych $\mathrm{w}$ porównaniu $\mathrm{z}$ grupą wychowywaną $\mathrm{w}$ rodzinach, jednak - co ważne - zauważono, że dzieci w opiece instytucjonalnej wykazują inny charakter zaburzeń w porównaniu z ich rówieśnikami mieszkającymi z rodziną (Tizard i Rees, 1975).

Inne brytyjskie badanie przeprowadzono w grupie wykazujących zaburzenia psychiczne uczniów w wieku 10-11 lat, uczęszczających do szkoły w jednej z dzielnic Londynu. Wykazano, że u tych osób, które korzystały z opieki państwowej, częstość zaburzeń wynosiła $17 \%$ - w porównaniu z jedynie $2 \%$ w grupie dzieci, które nigdy nie znajdowały się pod opieką państwa (Wolkind i Rutter, 1973).

McCann i wsp. (1996) zrealizowali badanie na grupie adolescentów w wieku 13-17 lat, która została skierowana pod opiekę państwa (zarówno do całodobowych placówek, jak i do opieki zastępczej). Wyniki porównano z grupą kontrolną. W badanej grupie rozpowszechnienie zaburzeń psychicznych wynosiło $57 \%$. Młodzież przebywająca w placówkach całodobowych wykazała zaburzenia psychiczne aż w $96 \%$ przypadków, w porównaniu z $57 \%$ w grupie młodzieży z opieki zastępczej.

W badaniach niemieckich rozpowszechnienie zaburzeń psychicznych u dzieci z placówek wychowawczych sięgało 80\% (Graf et al., 2002) oraz 59,9\% (Schmid, 2008; Schmid et al., 2008).

Innym przykładem są badania przeprowadzone $\mathrm{w}$ grupie dzieci na etapie przedszkolnym, znajdujących się w domach 
a population of children who had never been brought up in any institution was $22 \%$ (Bos et al., 2011).

Studies carried out in Turkey show that the frequency of mental disorders in Turkish institutionally reared children ranges from $18.3 \%$ to $47 \%$, however, in the overall population the frequency of mental disorder occurrence is only between $9 \%$ and 11\% (Erol et al., 2010).

In Poland, the first study focusing on mental condition among institutionally reared children and adolescents revealed a prevalence of mental disorders in orphanage children of 53.5\% (Pawliczuk and KaźmierczakMytkowska, 2014).

Data collected around the world correspond to the data obtained in Poland: institutionally reared children more often suffer from mental health problems. Comparing results from individual countries is troublesome due to differences in the childcare systems. These are just some examples from the world. Different forms of foster care in other countries prevent precise comparison, but the data suggest that children brought up in foster care present with more mental health problems than their peers raised in a full family, or even only by one of their biological parents.

The authors decided to establish whether there exists any relationship between institutional rearing and the type of mental disorders in the population of adolescents undergoing psychiatric treatment.

\section{MATERIAL}

Using the database established at the Department of Adolescent Psychiatry, University of Lodz, and covering the years 2006-2012, four groups were formed with patients categorised by their place of residence/type of guardianship they were provided with:

1. patients brought up by their parents;

2. patients brought up in foster families or adopted;

3. patients brought up in an orphanage or other institution;

4. patients brought up in other places such as hostels, dormitories and special education and care facilities.

\section{METHOD}

The four aforementioned groups were analysed with regard to sex, frequency of specific diagnostic categories, number of hospitalisations, age of mental disorder onset, self-injuries suffered from or suicide attempts made. For the purpose of simplification, mental disorders were divided into 11 groups as presented in Tab. 1 .

The sample group included 1,308 patients hospitalised at the Adolescent Psychiatry Ward, Central Teaching Hospital of the Medical University of Lodz, at which the research and teaching Department of Adolescent Psychiatry operates. The study participants included 794 girls and 514 boys aged $13-18$ years. Statistical analyses were carried out with use of the PQStat application, version 1.6.2.901. The diagnosis in specific dziecka i rodzinnych domach dziecka w Bukareszcie. W ciągu 54 miesięcy trwania badania $53 \%$ dzieci miało diagnozę psychiatryczną, podczas gdy w populacji dzieci nigdy niebędących w opiece instytucjonalnej odsetek ten wynosił 22\% (Bos et al., 2011).

Z kolei badania tureckie pokazały, że rozpiętość częstości zaburzeń psychicznych u dzieci podlegających pod opiekę instytucjonalną w tamtejszej populacji kształtuje się na poziomie od $18,3 \%$ do $47 \%$, a w populacji ogólnej jest to jedynie 9-11\% (Erol et al., 2010).

W Polsce pierwsze badanie nad kondycją psychiczną dzieci i młodzieży w opiece instytucjonalnej wykazało, że rozpowszechnienie zaburzeń psychicznych wśród dzieci z domów dziecka sięga 53,5\% (Pawliczuk i Kaźmierczak-Mytkowska, 2014).

Dane płynące z całego świata oraz z Polski są zbieżne: dzieci w opiece instytucjonalnej częściej mają problemy ze zdrowiem psychicznym. Problemem jest jednak porównywanie wyników z poszczególnych krajów z uwagi na różnice w systemach opieki nad dziećmi. Powyżej zawarte opisy badań to tylko niektóre przykłady ze świata. Różne formy pieczy zastępczej w innych krajach uniemożliwiają dokładne porównanie, jednak dane sugerują, że dzieci wychowane w pieczy zastępczej prezentują więcej problemów z zakresu zdrowia psychicznego niż ich rówieśnicy wychowywani w rodzinie pełnej lub nawet tylko przez jednego $\mathrm{z}$ biologicznych rodziców.

Autorzy postanowili zbadać, czy istnieje związek pomiędzy wychowaniem instytucjonalnym a rodzajem zaburzeń psychicznych w populacji młodzieży leczonej psychiatrycznie.

\section{MATERIAt}

Z bazy danych gromadzonych w latach 2006-2012 w Klinice Psychiatrii Młodzieżowej Uniwersytetu Medycznego w Łodzi wyodrębniono - ze względu na kryterium miejsca zamieszkania lub rodzaju sprawowanej nad nimi opieki cztery grupy pacjentów:

1. wychowywanych $\mathrm{z}$ rodzicami;

2. wychowywanych w pieczy zastępczej bądź adoptowanych;

3. wychowywanych w domu dziecka bądź innej instytucji;

4. wychowywanych w innych miejscach - rozumianych jako hostele, bursy, specjalne ośrodki szkolno-wychowawcze.

\section{METODA}

Dokonano analizy ww. czterech grup pod kątem płci, częstości grup rozpoznań, liczby hospitalizacji, wieku rozpoczęcia zaburzeń psychicznych, dokonywanych samouszkodzeń oraz dokonanych prób samobójczych. Dla uproszczenia zaburzenia psychiczne podzielono na 11 grup, zgodnie z obowiązującą w Polsce Międzynarodową Klasyfikacją Chorób ICD-10 (ICD-10; tab. 1).

Badaniu poddano 1308 pacjentów hospitalizowanych w latach 2006-2012 w Oddziale Psychiatrii Młodzieżowej Centralnego Szpitala Klinicznego Uniwersytetu Medycz- 


\begin{tabular}{|l|l|}
\hline 1 & F00-09 \\
\hline 2 & F10-19 \\
\hline 3 & F20-29 \\
\hline 4 & F30-39 \\
\hline 5 & F40-48 \\
\hline 6 & F50 \\
\hline 7 & F60-61 \\
\hline 8 & F70-79 \\
\hline 9 & F80-89 \\
\hline 10 & F90-98 \\
\hline 11 & $\begin{array}{l}\text { Other } \\
\text { Inne }\end{array}$ \\
\hline
\end{tabular}

Tab. 1. Diagnostic categories according to ICD-10

Tab. 1. Grupowanie rozpoznań zgodnie z klasyfikacja ICD-10

Sex, history of suicide attempts and self-injuries reported by the patients in specific groups were analysed based on chi-square test of independence. The number of hospitalisations and the age of mental disorder onset in specific groups were analysed based on the Kruskal-Wallis test and posthoc Dunn's test.

The test probability value at the level of $p<0.05$ was assumed to be significant, whereas at the level of $p<0.01$ it was considered highly significant.

\section{RESULTS}

Tab. 2 presents four groups of patients divided based on their place of residence and the type of care they were provided with as well as the rate of psychiatric diagnoses nego w Łodzi, przy którym działa Klinika Psychiatrii Młodzieżowej. Przebadana grupa składała się z 794 dziewcząt i 514 chłopców w wieku 13-18 lat.

Analizy statystyczne przeprowadzono za pomocą pakietu statystycznego PQStat w wersji 1.6.2.901. Rozpoznanie w poszczególnych grupach analizowano dokładnym testem Fishera.

Płeć, próby samobójcze i samouszkodzenia w wywiadzie przeprowadzonym w poszczególnych grupach zbadano testem niezależności chi ${ }^{2}$. Liczbę hospitalizacji i wiek wystąpienia zaburzeń psychicznych w poszczególnych grupach analizowano testem Kruskala-Wallisa oraz testem post-hoc Dunna.

Za istotne przyjęto prawdopodobieństwo testowe na poziomie $p<0,05$, a za wysoce istotne - prawdopodobieństwo testowe na poziomie $p<0,01$.

\section{WYNIKI}

W tab. 2 wyodrębniono cztery grupy pacjentów ze względu na miejsce zamieszkania lub rodzaj sprawowanej nad nimi opieki i przedstawiono częstość występowania rozpoznań psychiatrycznych, zgodnie $\mathrm{z}$ ich grupowaniem zawartym w tab. 1. Stwierdzono wysoce istotny związek $(p<0,0001)$ rozpoznania i grupy pod względem miejsca zamieszkania. W grupie młodzieży mieszkającej w placówce wykazano najwyższy odsetek zaburzeń zachowania (grupa rozpoznań F90-98) - 49,26\% pacjentów $\mathrm{z}$ tym rozpoznaniem zamieszkiwało w placówce. $\mathrm{Z}$ opiekunem niebędącym rodzicem zamieszkiwało $25 \%$ pacjentów z rozpoznaniami z grupy zaburzeń zachowania. Najniższy odsetek zaburzeń zachowania zaobserwowano

\begin{tabular}{|c|c|c|c|c|c|c|c|c|}
\hline \multirow{3}{*}{$\begin{array}{l}\text { Diagnosis } \\
\text { Rozpoznanie }\end{array}$} & \multicolumn{8}{|c|}{$\begin{array}{l}\text { Group } \\
\text { Grupa }\end{array}$} \\
\hline & \multicolumn{2}{|c|}{$\begin{array}{l}\text { With a parent } \\
\text { Zrodzicem }\end{array}$} & \multicolumn{2}{|c|}{$\begin{array}{l}\text { With a guardian } \\
\text { Zopiekunem }\end{array}$} & \multicolumn{2}{|c|}{$\begin{array}{l}\text { In an institution } \\
\text { Wplacówce }\end{array}$} & \multicolumn{2}{|c|}{$\begin{array}{l}\text { Other } \\
\text { Inne }\end{array}$} \\
\hline & $n$ & $\%$ & $n$ & $\%$ & $n$ & $\%$ & $n$ & $\%$ \\
\hline F00-09 & 24 & $2.29 \%$ & 4 & $4.88 \%$ & 2 & $1.47 \%$ & 2 & $4.54 \%$ \\
\hline F10-19 & 44 & $4.20 \%$ & 3 & $3.66 \%$ & 3 & $2.21 \%$ & 1 & $2.27 \%$ \\
\hline F20-29 & 188 & $17.96 \%$ & 5 & $6.10 \%$ & 6 & $4.41 \%$ & 7 & $15.91 \%$ \\
\hline F30-39 & 143 & $13.66 \%$ & 12 & $14.63 \%$ & 13 & $9.56 \%$ & 9 & $20.45 \%$ \\
\hline F40-48 & 315 & $30.09 \%$ & 29 & $35.37 \%$ & 25 & $18.38 \%$ & 9 & $20.45 \%$ \\
\hline F50 & 47 & $4.49 \%$ & & & & & 1 & $2.27 \%$ \\
\hline F60-61 & 6 & $0.57 \%$ & & & & & & \\
\hline F70-79 & 49 & $4.68 \%$ & 5 & $6.10 \%$ & 17 & $12.50 \%$ & 5 & $11.36 \%$ \\
\hline F80-89 & 23 & $2.20 \%$ & 1 & $1.22 \%$ & & & & \\
\hline F90-98 & 182 & $17.38 \%$ & 21 & $25.61 \%$ & 67 & $49.26 \%$ & 10 & $22.73 \%$ \\
\hline $\begin{array}{l}\text { Other } \\
\text { Inne }\end{array}$ & 26 & $2.48 \%$ & 2 & $2.44 \%$ & 3 & $2.21 \%$ & & \\
\hline
\end{tabular}

Tab. 2. Diagnosis in different groups of adolescent patients hospitalised due to mental problems

Tab. 2. Rozpoznanie w poszczególnych grupach nieletnich pacjentów hospitalizowanych psychiatrycznie 


\begin{tabular}{|c|c|c|c|c|c|c|c|c|}
\hline \multirow{3}{*}{$\begin{array}{l}\text { Sex } \\
\text { Pteć }\end{array}$} & \multicolumn{8}{|c|}{$\begin{array}{l}\text { Group } \\
\text { Grupa }\end{array}$} \\
\hline & \multicolumn{2}{|c|}{$\begin{array}{l}\text { With a parent } \\
\text { Z rodzicem }\end{array}$} & \multicolumn{2}{|c|}{$\begin{array}{l}\text { With a guardian } \\
\text { Zopiekunem }\end{array}$} & \multicolumn{2}{|c|}{$\begin{array}{l}\text { In an institution } \\
\text { Wplacówce }\end{array}$} & \multicolumn{2}{|c|}{$\begin{array}{l}\text { Other } \\
\text { Inne }\end{array}$} \\
\hline & $n$ & $\%$ & $n$ & $\%$ & $n$ & $\%$ & $n$ & $\%$ \\
\hline $\begin{array}{l}\text { Woman } \\
\text { Kobieta }\end{array}$ & 630 & $60.23 \%$ & 62 & $75.61 \%$ & 75 & $55.15 \%$ & 27 & $61.36 \%$ \\
\hline $\begin{array}{l}\text { Man } \\
\text { Mężzzyzna }\end{array}$ & 416 & $39.77 \%$ & 20 & $24.39 \%$ & 61 & $44.85 \%$ & 17 & $38.66 \%$ \\
\hline
\end{tabular}

Tab. 3. Sex distribution in different groups

Tab. 3. Płeć w poszczególnych grupach

\begin{tabular}{|c|c|c|c|c|c|c|c|c|}
\hline \multirow{3}{*}{$\begin{array}{l}\text { Suicide } \\
\text { attempt } \\
\text { Próba } \\
\text { samobójcza } \\
\text { w wywiadzie }\end{array}$} & \multicolumn{8}{|c|}{$\begin{array}{l}\text { Group } \\
\text { Grupa }\end{array}$} \\
\hline & \multicolumn{2}{|c|}{$\begin{array}{l}\text { With a parent } \\
\text { Zrodzicem }\end{array}$} & \multicolumn{2}{|c|}{$\begin{array}{l}\text { With a guardian } \\
\text { Zopiekunem }\end{array}$} & \multicolumn{2}{|c|}{$\begin{array}{l}\text { In an institution } \\
\text { W placówce }\end{array}$} & \multicolumn{2}{|c|}{$\begin{array}{l}\text { Other } \\
\text { Inne }\end{array}$} \\
\hline & $n$ & $\%$ & $n$ & $\%$ & $n$ & $\%$ & $n$ & $\%$ \\
\hline $\begin{array}{l}\text { No } \\
\text { Nie }\end{array}$ & 680 & $65.01 \%$ & 44 & $53.66 \%$ & 72 & $52.94 \%$ & 26 & $59.09 \%$ \\
\hline $\begin{array}{l}\text { Yes } \\
\text { Tak }\end{array}$ & 366 & $34.99 \%$ & 38 & $46.34 \%$ & 64 & $47.06 \%$ & 18 & $40.91 \%$ \\
\hline
\end{tabular}

Tab. 4. History of suicide attempts reported by patients from different groups

Tab. 4. Próba samobójcza w wywiadzie w poszczególnych grupach

\begin{tabular}{|c|c|c|c|c|c|c|c|c|}
\hline \multirow{3}{*}{$\begin{array}{l}\text { Self-injury } \\
\text { Samouszkodzenia } \\
\text { w wywiadzie }\end{array}$} & \multicolumn{8}{|c|}{$\begin{array}{l}\text { Group } \\
\text { Grupa }\end{array}$} \\
\hline & \multicolumn{2}{|c|}{$\begin{array}{l}\text { With a parent } \\
\text { Zrodzicem }\end{array}$} & \multicolumn{2}{|c|}{$\begin{array}{l}\text { With a guardian } \\
\text { Zopiekunem }\end{array}$} & \multicolumn{2}{|c|}{$\begin{array}{l}\text { In an institution } \\
\text { W placówce }\end{array}$} & \multicolumn{2}{|c|}{$\begin{array}{l}\text { Other } \\
\text { Inne }\end{array}$} \\
\hline & $n$ & $\%$ & $n$ & $\%$ & $n$ & $\%$ & $n$ & $\%$ \\
\hline $\begin{array}{l}\text { No } \\
\text { Nie }\end{array}$ & 644 & $61.51 \%$ & 29 & $35.37 \%$ & 45 & $33.09 \%$ & 20 & $45.45 \%$ \\
\hline $\begin{array}{l}\text { Yes } \\
\text { Tak }\end{array}$ & 403 & $38.49 \%$ & 53 & $64.63 \%$ & 91 & $66.91 \%$ & 24 & $54.55 \%$ \\
\hline
\end{tabular}

Tab. 5. Self-injuries reported by patients from different groups

Tab. 5. Samouszkodzenia w wywiadzie w poszczególnych grupach

according to the grouping showed in Tab. 1. A highly significant relationship $(p<0.0001)$ was found between the diagnosis and the place of residence. In the group of adolescents living in an institution the highest percentage of behavioural disorders was found (F90-98 diagnostic group): $49.26 \%$ of patients with this diagnosis lived in an institution. Twenty-five percent of patients with a diagnosis of behavioural disorders lived with a non-parent caregiver. The lowest rate of behavioural disorders was found in adolescents living with their parents. In children brought up in an institution the rate of depressive disorders was the lowest, while the highest rate of these disorders was found in subjects living with a non-parent caregiver.

A significant $\left(\mathrm{chi}^{2}=9.5048, d f=3, p=0.0233\right)$ relationship was established between sex and place of residence. In the w przypadku młodzieży mieszkającej z rodzicami. W grupie dzieci wychowywanych w placówce występował najniższy odsetek zaburzeń z grupy zaburzeń depresyjnych; największy odsetek tych zaburzeń odnotowano w grupie zamieszkującej z opiekunem niebędącym rodzicem.

Stwierdzono istotną $\left(\mathrm{chi}^{2}=9,5048, d f=3, p=0,0233\right) \mathrm{za}-$ leżność płci i grupy pod względem miejsca zamieszkania. W grupie pacjentów mieszkających z opiekunem stwierdzono najwyższy odsetek kobiet, a w grupie pacjentów mieszkających w placówce - najniższy (tab. 3).

Stwierdzono istotną $\left(\mathrm{chi}^{2}=11,0408, d f=3, p=0,0115\right)$ zależność prób samobójczych w wywiadzie i grupy pod względem miejsca zamieszkania. W grupie osób mieszkających z rodzicem odsetek stwierdzonych prób samobójczych w wywiadzie jest najniższy, a wśród mieszkających w placówce - najwyższy (tab. 4). 


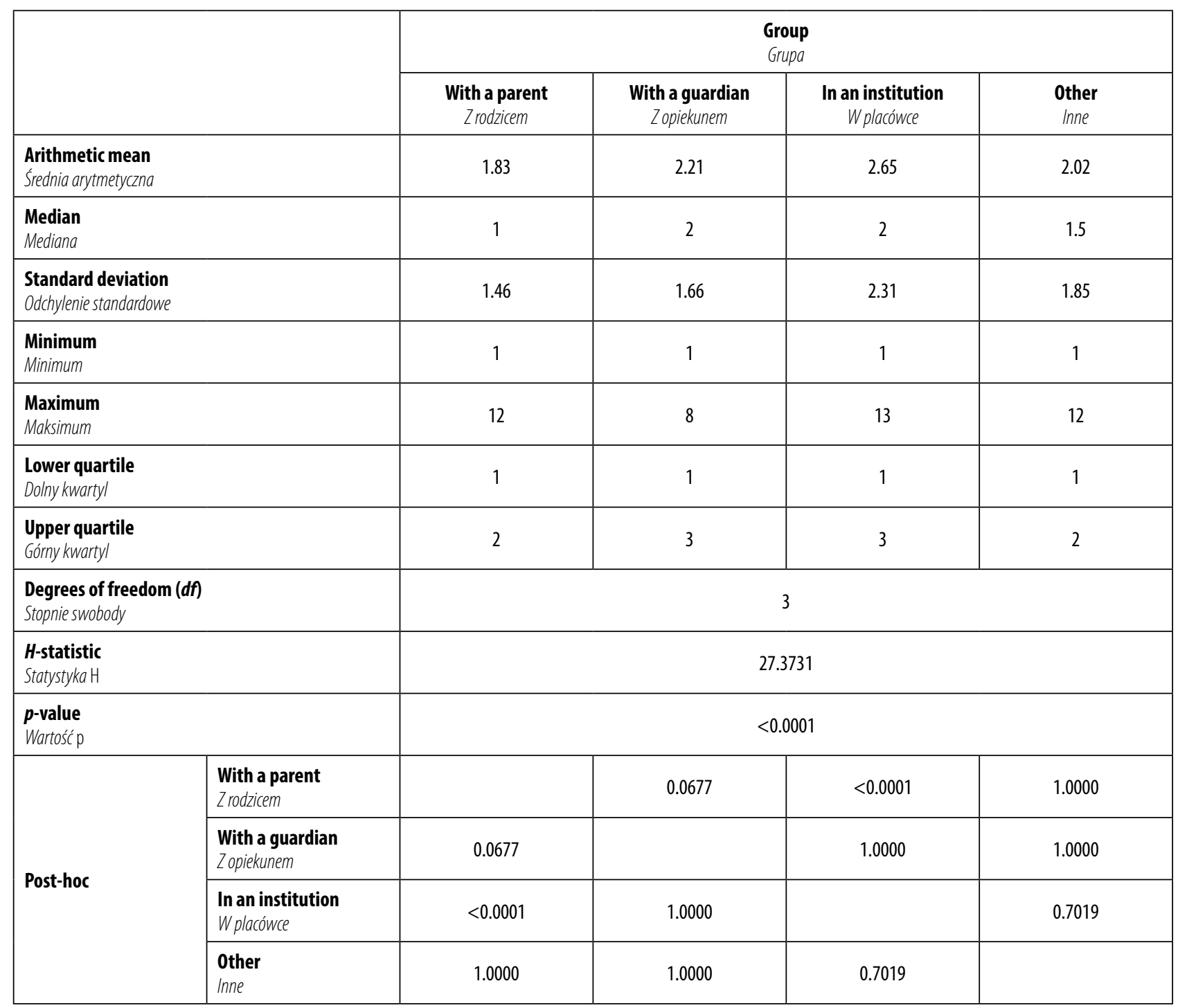

Tab. 6. Number of hospitalisations in different groups

Tab. 6. Liczba hospitalizacji w poszczególnych grupach

percentage rate of women and the lowest one is found in the group of patients living in an institution (Tab. 3).

A significant $\left(\mathrm{chi}^{2}=11.0408, d f=3, p=0.0115\right)$ relationship was established between reported suicide attempts and place of residence. In the group of patients living with their parents the percentage rate of reported suicide attempts was the lowest, whereas the highest rate was observed among those living in an institution (Tab. 4).

A significant $\left(\mathrm{chi}^{2}=58.0600, d f=3, p<0.0001\right)$ relationship was established between reported self-injuries and place of residence. In the group of patients living with their parents the percentage rate of reported self-injuries is the lowest and constitutes a minority of cases, whereas in the other groups it constitutes a majority with the highest number observed in the group of patients living in an institution (Tab. 5).

There is a statistically significant $(p<0.01)$ difference in the number of hospitalisations between individual groups.
Stwierdzono istotną $\left(\mathrm{chi}^{2}=58,0600, d f=3, p<0,0001\right)$ zależność samouszkodzenia w wywiadzie i grupy pod względem miejsca zamieszkania. W grupie dzieci mieszkających $\mathrm{z}$ rodzicem odsetek stwierdzonych samouszkodzeń w wywiadzie jest najniższy i stanowi mniejszość przypadków. W pozostałych grupach stanowi on większość, a najwyższy jest w grupie osób mieszkających w placówce (tab. 5).

Liczba hospitalizacji w poszczególnych grupach różni się istotnie statystycznie $(p<0,01)$ - najwyższe wyniki dotyczą grupy mieszkającej w placówce; są one wysoce istotnie większe od wyników uzyskanych wśród dzieci mieszkających $\mathrm{z}$ rodzicami (tab. 6).

Wiek wystąpienia zaburzeń psychicznych w poszczególnych grupach różni się istotnie statystycznie $(p<0,01)$ - najwyższe wyniki dotyczą grupy mieszkającej z rodzicami i są one wysoce istotnie większe od wyników uzyskanych w grupie mieszkającej w placówce (tab. 7). 


\begin{tabular}{|c|c|c|c|c|c|}
\hline & & \multicolumn{4}{|c|}{$\begin{array}{l}\text { Group } \\
\text { Grupa }\end{array}$} \\
\hline & & $\begin{array}{l}\text { With a parent } \\
\text { Z rodzicem }\end{array}$ & $\begin{array}{l}\text { With a guardian } \\
\text { Zopiekunem }\end{array}$ & $\begin{array}{l}\text { In an institution } \\
\text { W placówce }\end{array}$ & $\begin{array}{l}\text { Other } \\
\text { Inne }\end{array}$ \\
\hline \multicolumn{2}{|c|}{$\begin{array}{l}\text { Arithmetic mean } \\
\text { Średnia arytmetyczna }\end{array}$} & 13.75 & 12.85 & 12.80 & 13.32 \\
\hline \multicolumn{2}{|l|}{$\begin{array}{l}\text { Median } \\
\text { Mediana }\end{array}$} & 14 & 14 & 13 & 14 \\
\hline \multicolumn{2}{|c|}{$\begin{array}{l}\text { Standard deviation } \\
\text { Odchylenie standardowe }\end{array}$} & 2.97 & 3.60 & 3.35 & 3.63 \\
\hline \multicolumn{2}{|l|}{$\begin{array}{l}\text { Minimum } \\
\text { Minimum }\end{array}$} & 0 & 0 & 0 & 2 \\
\hline \multicolumn{2}{|l|}{$\begin{array}{l}\text { Maximum } \\
\text { Maksimum }\end{array}$} & 22 & 17 & 18 & 18 \\
\hline \multicolumn{2}{|c|}{$\begin{array}{l}\text { Lower quartile } \\
\text { Dolny kwartyl }\end{array}$} & 13 & 12 & 11 & 12 \\
\hline \multicolumn{2}{|c|}{$\begin{array}{l}\text { Upper quartile } \\
\text { Górny kwartyl }\end{array}$} & 16 & 15 & 15 & 16 \\
\hline \multicolumn{2}{|c|}{$\begin{array}{l}\text { Degrees of freedom (df) } \\
\text { Stopnie swobody }\end{array}$} & \multicolumn{4}{|c|}{3} \\
\hline \multicolumn{2}{|l|}{$\begin{array}{l}\text { H-statistic } \\
\text { Statystyka H }\end{array}$} & \multicolumn{4}{|c|}{15.8583} \\
\hline \multicolumn{2}{|l|}{$\begin{array}{l}\boldsymbol{p} \text {-value } \\
\text { Wartośćp }\end{array}$} & \multicolumn{4}{|c|}{0.0012} \\
\hline \multirow{4}{*}{ Post-hoc } & $\begin{array}{l}\text { With a parent } \\
\text { Zrodzicem }\end{array}$ & & 0.1469 & 0.0031 & 1.0000 \\
\hline & $\begin{array}{l}\text { With a guardian } \\
\text { Zopiekunem }\end{array}$ & 0.1469 & & 1.0000 & 1.0000 \\
\hline & $\begin{array}{l}\text { In an institution } \\
\text { W placówce }\end{array}$ & 0.0031 & 1.0000 & & 0.8514 \\
\hline & $\begin{array}{l}\text { Other } \\
\text { Inne }\end{array}$ & 1.0000 & 1.0000 & 0.8514 & \\
\hline
\end{tabular}

Tab. 7. The age of mental disorder onset in different groups

Tab. 7. Wiek wystąpienia zaburzeń psychicznych w poszczególnych grupach

The highest numbers refer to the group of patients living in an institution and they are statistically significantly higher than the results obtained in the group of patients living with parents (Tab. 6).

There is a statistically significant $(p<0.01)$ difference in the age of mental disorder onset between individual groups. The highest numbers refer to the group of patients living with parents and they are statistically significantly higher than the results observed in the group of patients living in an institution (Tab. 7).

\section{Summary of the results}

1. In the group of patients included in the study, girls were more often brought up in foster families.

2. In institutional rearing facilities the sex distribution is even.

\section{Podsumowanie wyników}

1. W badanej grupie pieczą zastępczą częściej objęte były dziewczynki.

2. W placówkach wychowania instytucjonalnego rozkład płci jest równomierny.

3. Najczęstsze rozpoznania, z którymi hospitalizowane są dzieci wychowywane w instytucji, stanowią zaburzenia zachowania i emocji (grupa rozpoznań F90-F98); prawie połowa badanych wykazała zaburzenia $\mathrm{z}$ tej grupy.

4. Odsetek samouszkodzeń i prób samobójczych jest wyższy w grupach dzieci wychowywanych w pieczy zastępczej i w placówkach opiekuńczo-wychowawczych.

5. Średnia wieku zapadania na zaburzenia psychiczne jest niższa w przypadku pieczy zastępczej i wychowania instytucjonalnego. 
3. The most common types of diagnosis due to which institutionally reared children have been hospitalised are behavioural and emotional disorders (diagnostic categories from F90 to F98); almost half of the study subjects showed this type of disorders.

4. The percentage rate of self-injuries and suicide attempts is higher in groups of children brought up in foster families and education and care facilities.

5. The average age of developing mental disorders is lower in children brought up in foster families and institutions.

6. In the group of children brought up in foster families and institutions, a higher number of hospitalisations were observed.

\section{DISCUSSION}

The presented subject is extremely important from the point of a children and adolescents psychiatrist view. Children from orphanages and foster families constitute a significant percentage of the psychiatric patient population. Unfortunately, despite the attempts at systemic changes, institutional upbringing is conducive to the development of mental disorders. Therefore, the presented data indicate how important a background survey is at the initial stage of the doctor's contact with the young patient. The form of care that the child is provided with cannot be disregarded and indicates potential threats.

The presented results are consistent with the literature on the subject. Already in the 1970s, in the United Kingdom, an increased incidence of psychiatric disorders was observed in children in whom care was interfered with by the state (Tizard and Rees, 1975; Wolkind and Rutter, 1973). The results of research from the United Kingdom, the United States of America, Germany, Turkey and Romania indicate that the percentage of mental disorders in children raised in various forms of foster care was significantly higher than in the case of children raised by the family (Graf et al., 2002; Jackson et al., 2010; McCann et al., 1996; Schmid, 2008; Schmid et al., 2008; Tizard and Rees, 1975; Wolkind and Rutter, 1973). Comparing results from different countries is problematic, since each country has its own system of caring for orphaned children.

The advantage of this work is a relatively large research group (children and adolescents from the Łódź region) in comparison with the research carried out in other countries. Patients' diagnoses were grouped according to the main categories of the ICD-10 classification applicable in Poland (Pużyński and Wciórka, 2000). So far, only studies in Warsaw children's homes in Poland (Pawliczuk and Kaźmierczak-Mytkowska, 2014), which have provided epidemiological data on mental disorders of children and adolescents, have been carried out. Currently, this is the first study collecting data from the Łódź region among hospitalised children raised in substitute forms of care.

An issue requiring further development is the extension of the research group to populations of community
6. W grupie dzieci w pieczy zastępczej i wychowaniu instytucjonalnym zaobserwowano większą liczbę hospitalizacji.

\section{OMÓWIENIE}

Przedstawiony temat jest niezwykle istotny z punktu widzenia lekarza psychiatry dzieci i młodzieży. Wychowankowie domów dziecka i rodzin zastępczych stanowią znaczący odsetek populacji pacjentów psychiatrycznych. Niestety wciąż - pomimo podejmowania prób zmian systemowych - wychowanie instytucjonalne sprzyja rozwojowi zaburzeń psychicznych. Zaprezentowane dane pokazują więc, jak istotny jest wywiad środowiskowy już na początkowym etapie kontaktu lekarza z młodym pacjentem. Forma opieki, którą objęte jest dziecko, nie może być pomijana, wskazuje bowiem na potencjalne zagrożenia.

Prezentowane wyniki są zgodne z literaturą przedmiotu. Już w latach 70. ubiegłego wieku w Wielkiej Brytanii zauważono zwiększoną częstość zaburzeń psychicznych u dzieci, w których opiekę ingerowało państwo (Tizard i Rees, 1975; Wolkind i Rutter, 1973). W przedstawionych wynikach badań z Wielkiej Brytanii, Stanów Zjednoczonych, Niemiec, Turcji i Rumunii odsetek zaburzeń psychicznych u dzieci wychowywanych w różnych formach opieki zastępczej był istotnie wyższy niż w przypadku dzieci wychowywanych w rodzinie (Graf et al., 2002; Jackson et al., 2010; McCann et al., 1996; Schmid, 2008; Schmid et al., 2008; Tizard i Rees, 1975; Wolkind i Rutter, 1973). Problem stanowi porównywanie wyników uzyskanych w różnych krajach, gdyż poszczególne państwa mają swoje odrębne systemy opieki nad dziećmi osieroconymi.

Atutem pracy jest stosunkowo duża grupa badana (dzieci i młodzież z województwa łódzkiego) w porównaniu z badaniami przeprowadzonymi w innych krajach. Rozpoznania u pacjentów zostały zgrupowane zgodnie z głównymi kategoriami klasyfikacji ICD-10 (Pużyński i Wciórka, 2000). Dotychczas w Polsce przeprowadzono jedynie badania w warszawskich domach dziecka (Pawliczuk i KaźmierczakMytkowska, 2014), które dostarczyły danych epidemiologicznych na temat zaburzeń psychicznych dzieci i młodzieży. Aktualnie więc jest to pierwsza praca zbierająca dane $\mathrm{z}$ województwa łódzkiego wśród dzieci hospitalizowanych, które są wychowywane w zastępczych formach opieki.

Kwestią wymagającą dalszego opracowania jest rozszerzenie grupy badawczej o populacje pacjentów podlegających pod opiekę środowiskową i ambulatoryjną. Również badania brytyjskie i rumuńskie cechowały się ograniczoną populacją i obszarem badania. Fakt ten ukazuje potrzebę przeprowadzenia szeroko zakrojonych analiz epidemiologicznych w celu uzyskania najbardziej rzetelnych wyników, co w przyszłości przełożyłoby się na niesienie skutecznej pomocy psychiatrycznej dzieciom $z$ tej grupy ryzyka.

Z uwagi na charakter pracy (retrospektywną analizę dokumentacji) dane nie były na tyle kompletne, aby umożliwić porównanie wieku, w którym pacjenci zostali objęci pieczą zastępczą bądź wychowaniem instytucjonalnym. 
and outpatient care subjects. Similarly, the British and Romanian studies were characterised by a limited population and area of study. This fact illustrates the need for extensive epidemiological research in order to obtain the most reliable results which in the future would translate into effective psychiatric help for children from this risk group. Due to the nature of the work (retrospective analysis of documentation), the data was not complete enough to allow comparison of the age at which patients were provided with foster or institutional care. In further studies, it would be advisable to analyse the association between the type of disorder and its severity, and the age at which the child was included in these forms of care.

It should be emphasised that the presented clinical differences between the studied groups can also be due to the decisions of doctors admitting an adolescent at the psychiatric admissions department. Perhaps the information that a patient lives in an institution makes them more likely to be admitted than their peers living with their parents, even with a comparable severity of suicidal thoughts. Another possible explanation is the fact that parents are less likely to report to a psychiatrist due to the risk of suicide in their child than caregivers from an institution. The hypothesis stated above may be corroborated by the fact that the highest number of successful suicide attempts take place in the family home rather than in education and care facilities. The hypotheses presented above can have an impact on the results, but they do require appropriate investigation and verification.

In conclusion, different forms of foster care, despite providing children with livelihood, do not allow them to fully satisfy their emotional needs. This results in a higher percentage of mental disorders than in the general population, a higher percentage of suicide attempts and self-injuries as well as relatively more frequent hospitalisations. This fact is a challenge for foster care systems and indicates further directions of their necessary development in order to provide comprehensive care for a child in a difficult life situation.

\section{CONCLUSIONS}

1. Based on the sex analysis it may be concluded that girls are much more often brought up in foster families than boys.

2. Children and adolescents brought up in institutions suffer from self-injuries and make suicide attempts more often than their peers raised by two-parent or even foster families.

3 . The average age of mental disorder onset among children brought up in institutions and foster families is lower than among their peers raised in regular families.

4. Children brought up in foster families and institutions are hospitalised more often than their peers raised in regular families.

5. Institutional rearing is a factor that gives a poorer prognosis for mental disorders among children and adolescents, just as living with a non-parent caregiver (a guardian).
W dalszych badaniach wskazana byłaby zatem dokładna analiza związku pomiędzy rodzajem zaburzeń i ich nasileniem a wiekiem, w którym dziecko zostało objęte tymi formami opieki.

Należy podkreślić, że zaprezentowane różnice w obrazie klinicznym badanych grup mogą również wynikać z decyzji lekarzy przyjmujących nastolatka w psychiatrycznej izbie przyjęć. Być może informacja o opiece instytucjonalnej wpływa na decyzję lekarza w taki sposób, że dzieci niemieszkające z rodzicami są przyjmowane częściej niż ich rówieśnicy mieszkający z rodzicami - nawet przy porównywalnym nasileniu myśli samobójczych. Innym możliwym wyjaśnieniem jest fakt, że rodzice rzadziej zgłaszają się do psychiatry z powodu wystąpienia ryzyka samobójczego u dziecka niż opiekunowie $\mathrm{z}$ instytucji. Pewną wskazówką potwierdzającą powyższą hipotezę jest informacja, że więcej skutecznych prób samobójczych nastolatków ma miejsce w domu rodzinnym, a nie w instytucjach opiekuńczo-wychowawczych. Zaprezentowane powyżej hipotezy mogą wpływać na wyniki, jednak wymagają odpowiedniego zbadania i weryfikacji.

Podsumowując, formy opieki zastępczej pomimo zapewnienia dzieciom bytu nie pozwalają w pełni zaspokoić ich potrzeb emocjonalnych. Wynikiem tego są wyższy niż w populacji ogólnej odsetek zaburzeń psychicznych, wyższy odsetek prób samobójczych i samouszkodzeń, a także stosunkowo częstsze hospitalizacje. Fakt ten stanowi wyzwanie dla systemów opieki zastępczej i wskazuje dalsze kierunki ich niezbędnego rozwoju w celu zapewniania kompleksowej opieki nad dzieckiem znajdującym się w trudnej sytuacji życiowej.

\section{WNIOSKI}

1. Na podstawie analizy płci można wyciągnąć wniosek, że w badanej populacji pieczą zastępczą o wiele częściej objęte są dziewczynki niż chłopcy.

2. Dzieci i młodzież wychowywane w placówkach częściej dokonują samouszkodzeń i prób samobójczych niż ich rówieśnicy z rodzin pełnych, a nawet zastępczych.

3. Dzieci w wychowaniu instytucjonalnym oraz w pieczy zastępczej odznaczają się niższą średnią wieku, w którym zapadają na zaburzenia psychiczne, niż ich rówieśnicy wychowywani w rodzinie.

4. Dzieci z pieczy zastępczej oraz wychowania instytucjonalnego są częściej hospitalizowane od ich rówieśników wychowywanych z rodzicami.

5. Wychowanie instytucjonalne jest czynnikiem pogarszającym rokowanie w zaburzeniach psychicznych dzieci i młodzieży, podobnie jak zamieszkiwanie z opiekunem niebędącym rodzicem.

\section{Konflikt interesów}

Oświadczamy, że nie występuje konflikt interesów. 


\section{Conflict of interest}

The authors declare no conflict of interest.

\section{References / Piśmiennictwo}

Bos K, Zeanah CH, Fox NA et al.: Psychiatric outcomes in young children with a history of institutionalization. Harv Rev Psychiatry 2011; 19: 15-24.

Erol N, Simsek Z, Münir K: Mental health of adolescents reared in institutional care in Turkey: challenges and hope in the twentyfirst century. Eur Child Adolesc Psychiatry 2010; 19: 113-124.

Graf E, Bitzer M, Zimmermann-Wagner M: Herausforderung Kinderdorf - Ergebnisse der Kinderdorf-Effekte-Studie (KES). Unsere Jugend 2002; 12: 527-539. Za: Schmid M, Goldbeck L, Nuetzel J, Fegert JM: Prevalence of mental disorders among adolescents in German youth welfare institutions. Child Adolesc Psychiatry Ment Health 2008; $2: 2$.

Jackson LJ, White CR, O’Brien $\mathrm{K}$ et al.: Exploring spirituality among youth in foster care: findings from the Casey Field Office Mental Health Study. Child Fam Soc Work 2010; 15: 107-117.
McCann JB, James A, Wilson S et al.: Prevalence of psychiatric disorders in young people in the care system. BMJ 1996; 313: 1529-1530.

Pawliczuk W, Kaźmierczak-Mytkowska A: Zaburzenia psychiczne oraz potrzeby terapeutyczne dzieci i młodzieży przebywających w placówkach opiekuńczo-wychowawczych (domach dziecka). Psychiatr Psychol Klin 2014; 14: 140-144.

Pużyński S, Wciórka J: Klasyfikacja zaburzeń psychicznych i zaburzeń zachowania w ICD-10. Opisy kliniczne i wskazówki diagnostyczne. Vesalius, Kraków 2000.

Schmid M: Children and adolescents in German youth welfare institutions. European Psychiatric Review 2008; 1: 10-12.

Schmid M, Goldbeck L, Nuetzel J et al.: Prevalence of mental disorders among adolescents in German youth welfare institutions. Child Adolesc Psychiatry Ment Health 2008; 2: 2.

Tizard B, Rees J: The effect of early institutional rearing on the behaviour problems and affectional relationships of four-year-old children. J Child Psychol Psychiatry 1975; 16: 61-73.

Wolkind S, Rutter M: Children who have been "in care" - an epidemiological study. J Child Psychol Psychiatry 1973; 14: 97-105. 